Original Article

\title{
PHYSICO-CHEMICAL CHARACTERISTICS OF RUSSIAN TEA FUNGUS: KOMBUCHA
}

\author{
SUMAIYA AHMED ALI, GUNASHREE B. SHIVANNA*
}

Department of Studies and Research in Microbiology, Mangalore University Post Graduate Centre, Chikka Aluvara, Kodagu 571232, Karnataka, India

Email: gunashree_bs@yahoo.co.in

Received: 23 Dec 2016 Revised and Accepted: 27 Feb 2017

\section{ABSTRACT}

Objective: To characterize various physicochemical parameters for Russian tea fungus: Kombucha.

Methods: In the present investigation, various physicochemical analyses of kombucha such as, estimation of biomass, ascorbic acid, acetic acid, carotenoid contents, antioxidant activity and antibacterial activity against E. coli, Salmonella sp and Staphylococcus aureus were carried out after growing at different temperature and $\mathrm{pH}$ with varied concentrations of 5, 10, 15 and 20\% tea powder boiled for 10 min along with $5 \%$ sugar and filtered to obtain tea decoction.

Results: The bacteria in kombucha were Gram-negative, flexible rods. Both bacteria and yeast were positive for acid and gas production with glucose and sucrose and negative with lactose. A highest biomass content of 33.39 and $32.9 \mathrm{~g} / \mathrm{l}$ in 5 and $10 \%$ tea decoction respectively was observed when grown statically at $25{ }^{\circ} \mathrm{C}$ and $\mathrm{pH} 5.0$. Highest carotenoids $(92.5 \mu \mathrm{g} / \mathrm{ml})$ content was found at normal pH without setting, while 85 and $84 \mu \mathrm{g} / \mathrm{ml}$ at $\mathrm{pH} 4.5$ and 5.0 respectively under static condition. A highest DPPH(2,2-diphenyl-1-picrylhydrazyl) inhibition of 76.95\% with IC 50 value $3.26 \mu \mathrm{g} / \mathrm{ml}$ and ascorbic acid content of $33.19 \%$ were found with $5 \%$ tea at $25^{\circ} \mathrm{C}$ and pH 4.5 . Acetic acid, which was shown to be one of the antimicrobial agents in kombucha had the highest strength of $2.25 \mathrm{~g} / \mathrm{l}$ in $5 \%$ tea grown at $25{ }^{\circ} \mathrm{C}$ and normal pH, while $4.5 \mathrm{~g} / \mathrm{l}$ at pH 4.5 . The antibacterial activity showed the sensitivity of Escherichia Coli with $57 \%$ and Salmonella sp with $42.9 \%$ inhibition for $k o m b u c h a$ grown at $25{ }^{\circ} \mathrm{C}$ and $\mathrm{pH} 4.5$ when compared to positive control.

Conclusion: Kombucha, a miracle drink can be exploited furthermore for human well-being through combating various health issues due to changing lifestyle.

Keywords: Kombucha, SCOBY, Fermented tea, Antioxidant, Antimicrobial

(C) 2017 The Authors. Published by Innovare Academic Sciences Pvt Ltd. This is an open access article under the CC BY license (http://creativecommons.org/licenses/by/4.0/) DOI: http://dx.doi.org/10.22159/ijpps.2017v9i4.16753

\section{INTRODUCTION}

"KOMBUCHA" is a fermented tea made with a symbiotic culture of bacteria and yeast (SCOBY). The kombucha broth has two portions, a floating cellulosic pellicle layer and the sour liquid broth. The liquid broth is known to have acetic acid, ethanol and gluconic acid as major components [1]. It is a traditional fermentation carried out by inoculating previously grown mother culture into fresh tea decoction and incubating statically under aerobic conditions at room temperature for $10-15 \mathrm{~d}$

Eventually, a pleasantly sour beverage called kombucha is obtained [2] which is claimed to have high human prophylactic properties $[1,3,4]$. Kombucha is also considered as a probiotic microbial drink, which helps regenerate the bowel flora and is excellent for well-being. The kombucha culture feeds on the sugar and in exchange produces other valuable substances such as glucuronic acid, acetic acid, lactic acid, vitamins, amino acids, antibiotic substances and 0.5-1\% alcohol.

Kombucha is a highly palatable health beverage due to its beneficial effects such as antibiotic properties, regulation of gastric, intestinal and glandular activities, relief of joint rheumatism, gout and haemorrhoids, positive influence on the cholesterol level, atherosclerosis, toxin excretion and blood cleansing, diabetes, nervousness and aging problems [5]. Because of its highly beneficial nature, the present study was focused on estimation of biomass, ascorbic acid, acetic acid, carotenoid contents, antioxidant activity and antibacterial activity against E. coli, Salmonella spand Staphylococcus aureus in kombucha.

\section{MATERIALS AND METHODS}

\section{Mother culture of SCOBY}

The symbiotic culture of bacteria and yeast was obtained from a local household brewer from Mangalore, India.

\section{Microbial strains}

The bacterial cultures such as Escherichia coli, Salmonella and Staphylococcus aureus used in the study were collected from the stock of the Department of Studies and Research in Microbiology, Mangalore University, Post Graduate Centre, Kodagu.

\section{Chemicals and reagents}

Acetic acid, agar, alcohol (75, 95 and 100\%), ammonium dihydrogen phosphate, Ammonium sulphate, Ascorbic acid, $\alpha$-naphtholamine, beef extract, bromothymol blue, $\beta$-carotene, $\beta$-naphthol, crystal violet, dipotassium hydrogen phosphate, 2,2-diphenyl-1-picrylhydrazyl (DPPH), ferrous sulphate, gelatin, glucose, Gram's Iodine, hydrogen peroxide, lactose, malachite green, magnesium sulphate, mercuric chloride, methyl red, peptone, phenol red, potassium dihydrogen phosphate, potassium hydroxide, potassium nitrate, potassium chloride, potassium iodide, potassium ferricyanide, safranin, sodium chloride, sodium citrate, sodium thiosulphate, sodium carbonate, sucrose, sodium hydroxide, starch, tetramethyl p-phenylenediamine dihydrochloride, trichloroacetic acid, urea and yeast extract were used in the present study.

All the chemicals and reagents were of extra pure and analytical grade and were procured from Hi-Media, Mumbai, India and Sisco Research Laboratory, Bangalore, India.

\section{Microscopic identification and biochemical tests of Kombucha}

The symbionts were microscopically identified by preparing a semipermanent slide using lactophenol cotton blue stain. The bacteria were identified based on morphological characteristics such as color, margin, elevation, transparency, texture, form, shape [6], Gram staining technique and biochemical tests such as indole, methyl red, Voges-Proskauer, citrate utilization, catalase, urease, $\mathrm{H}_{2} \mathrm{~S}$ production, starch and gelatin hydrolysis, carbohydrate fermentation using glucose, sucrose and lactose. 


\section{Brewing Kombucha}

Different concentrations $(5,10,15$ and 20\%) of tea decoction were prepared by boiling appropriate amount of tea powder for $10 \mathrm{~min}$ and then strained. The concentration of sugar was maintained at $5 \%$ for all the above tea concentrations. $100 \mathrm{ml}$ aliquot was poured into sterile $250 \mathrm{ml}$ Erlen Mayer's flask and inoculated with 5-10\% of mature kombucha. This acidifies the tea which is important for maintaining a selective environment that favours the SCOBY and prevents potential contaminants from developing. This was followed by aseptic addition of mother culture at $1 \%(\mathrm{~g} /$ wet $\mathrm{wt}$ ) level and maintaining at room temperature until SCOBY grows completely like a pellicle.

\section{Optimization of temperature and concentration of tea for the growth of SCOBY}

The above mentioned different concentrations of tea decoction were made and kombucha was inoculated with $1 \%$ mother culture. The flasks were incubated for $7 \mathrm{~d}$ under both static and rotary conditions at various temperatures from 25 to $45^{\circ} \mathrm{C}$ with an interval of $5{ }^{\circ} \mathrm{C}$. After incubation, all the samples were subjected to various biochemical and growth tests such as radical scavenging activity using DPPH free radical, estimation of ascorbic acid and acetic acid by titration methods, carotenoid estimation by spectrophotometric method, antimicrobial activity and biomass determination with appropriate standard procedures.

\section{Optimization of $\mathrm{pH}$ for the growth of $S \mathrm{COBY}$}

After determining the optimum temperature and concentration of tea decoction, $\mathrm{pH}$ was set from 3.0 to 7.5 with an interval of $\mathrm{pH} 0.5$. After incubating for $7 \mathrm{~d}$ all the samples were subjected to various biochemical and growth tests as mentioned previously.

After 7days of incubation kombucha was centrifuged in a cooling centrifuge at 5,000 rpm for $10 \mathrm{~min}$. The aqueous contents were used for all the biochemical analyses and growth parameters.

\section{DPPH assay}

Antioxidant activity of kombucha was determined through DPPH free radical scavenging assay carried out by the method of De Ancos et al., (2002) [7]. The procedure, in brief, is as follows: $10 \mu \mathrm{L}$ of centrifuged sample mixed with $90 \mu \mathrm{L}$ of methanol and $3.9 \mathrm{ml}$ of 0.1 mmol methanolic DPPH solutions. The mixture was thoroughly vortexed, kept in the dark for $30 \mathrm{~min}$ and absorbance read at 515 nm. Percentage inhibition of DPPH was calculated using the following formula.

\% inhibition of DPPH $=\frac{\text { Absorption of control -Absorption of sample }}{\text { Absorption of control }} \times 100$

\section{Carotenoid estimation}

The sample after incubation period was centrifuged at $5000 \mathrm{rpm}$ for 10 min at $4{ }^{\circ} \mathrm{C}$. The samples were kept away from light, and their absorbance was read at $450 \mathrm{~nm}$ [8].

\section{Estimation of strength of acetic acid}

The strength of an acetic acid in kombucha was determined by titrimetric method [9]. The method, in brief, is as follows: $1.5 \mathrm{ml}$ of kombucha sample was made up to $20 \mathrm{ml}$ with distilled water, to which 3 drops of phenolphthalein indicator was added and titrated against $0.1 \mathrm{M} \mathrm{NaOH}$ until the colour changed to pale pink as an end point. Acetic acid strength was determined by the formula:

$$
\begin{gathered}
\text { Concentration of acetic acid }=\frac{1.5 \times \text { Vol of } \mathrm{NaOH}}{\text { Vol of reaction migture }(20 \mathrm{ml})}=\mathrm{Xmol} / \mathrm{l} \\
\text { Strength of acetic acid }=\mathrm{X} \times 60=\mathrm{Y} \text { gll }
\end{gathered}
$$

\section{Estimation of ascorbic acid}

Ascorbic acid content in kombucha was determined by titrimetric method [10]. The method, in brief, is as follows: $5 \mathrm{ml}$ of the sample was transferred into $250 \mathrm{ml}$ Erlenmeyer flask to which $35.6 \mathrm{ml}$ distilled water and $0.3 \mathrm{ml}$ starch indicator was added. The mixture was titrated against $5 \mathrm{mmol}$ Iodine solution. The end point was identified as a permanent trace of dark blue colour. Percentage of ascorbic acid was determined by the following formula:

$$
\text { Normality of ascorbic acid }=\frac{\mathrm{NzV}}{\text { Volume of sample }}
$$

\section{Antimicrobial activity of Kombucha}

Antimicrobial activity of kombucha was determined by agar well diffusion method [11]. The method is as follows: Nutrient agar medium plates were prepared and known bacteria to be tested for susceptibility were swabbed and agar wells were made using a 6 mm sterile cork borer, into which $30 \mu \mathrm{l}$ of kombucha was transferred and the plates were incubated at $37^{\circ} \mathrm{C}$ for $24 \mathrm{~h}$. The plates were observed for clear zones around the wells.

\section{Biomass determination}

After $7 \mathrm{~d}$ of incubation, the thick pellicle of SCOBY formed on the surface of tea decoction was removed, an excess of moisture was removed by blotting and its wet weight was recorded as gram wet weight/litre (gww/l).

The dry weight was determined by drying the culture pellet at $100^{\circ} \mathrm{C}$ in a hot air oven for overnight or until getting constant weight and was recorded as gram dry weight/litre (gdw/l).

\section{Statistical analysis}

Data, expressed as mean $\pm \mathrm{SD}$ was statistically analyzed using oneway ANOVA. Duncan's multiple tests were used to compare means and significance was accepted at $\mathrm{P}<0.05$ [12].

\section{RESULTS AND DISCUSSION}

\section{Biochemical characterization of SCOBY}

The bacteria and yeast in kombucha were characterized based on various biochemical parameters such as Gram staining, motility test, endospore formation, catalase test, urease production, $\mathrm{H}_{2} \mathrm{~S}$ production, indole, methyl red, Voges-Proskauer, citrate utilization test, gelatin and starch hydrolysis, glucose, lactose and sucrose fermentation test. The results are summarised in table 1.

Table 1: Biochemical characterization of bacteria and fungus in Kombucha optimization of temperature for biochemical parameters

\begin{tabular}{ll}
\hline Parameters & Results \\
\hline Bacteria & Gram-ve, flexible rods \\
Gram reaction & + \\
Motility & + \\
Endospore formation & + \\
Catalase & + \\
Citrate utilization & + \\
Urease production & + \\
H2S production & - \\
Indole test & + \\
Methyl Red & - \\
Voges-Proskauer & + \\
Gelatin hydrolysis & + \\
Starch hydrolysis & acid $^{+}$gas $^{+}$ \\
Glucose fermentation & acid $^{-g^{-}}$ \\
Lactose fermentation & acid $^{+}$gas $^{+}$ \\
Sucrose fermentation & \\
Fungus & Reaction $^{+}$ \\
Carbohydrate tested & acid $^{+}$gas $^{+}$ \\
Sucrose & acid gas $^{+}$ \\
Glucose & acid-gas $^{-}$ \\
Lactose &
\end{tabular}

Abbreviation: '+' Positive test; '-'Negative test 
The results obtained showed that the bacterium is a motile, Gramnegative, flexible rod, an endospore former, positive for catalase, citrate utilization, urease and $\mathrm{H}_{2} \mathrm{~S}$ production, methyl red test, gelatin and starch hydrolysis, while it was negative for indole production and Voges-Proskauer test. Fermentation of sugars such as glucose, lactose and sucrose showed acid and gas positive for glucose and sucrose while it was negative for lactose. Similar fermentation study was also carried out for yeast using same three sugars and the result obtained was similar to that for bacteria (table 1). From the results obtained through various biochemical parameters, it could be concluded that the bacterium found in scoby may be Acetobacter sps and yeast may be Schizosaccharomyces sps.

The SCOBY was cultivated at different temperatures ranging from 25$45^{\circ} \mathrm{C}$ with an interval of $5^{\circ} \mathrm{C}$. The tea decoctions $(5,10,15,20 \%)$ were inoculated with $1 \%$ inoculum and incubated at the above-mentioned temperatures and either under static or rotary conditions. The results shown in table 2 are only for the static condition since the data obtained for rotary conditions were insignificant. The results showed the highest biomass of $33.39 \mathrm{~g} / \mathrm{l}$ at $25^{\circ} \mathrm{C}$ with $5 \%$ tea decoction followed by $10 \%$ showing $32.99 \mathrm{~g} / \mathrm{l}$ which was not significantly different from that of $5 \%$. At other temperatures such as $30,35,40$ and $45^{\circ} \mathrm{C}$, the biomass contents significantly reduced. The highest total carotenoid content of $92.5 \mu \mathrm{g} / \mathrm{ml}$ was found at $25^{\circ} \mathrm{C}$ with $5 \%$ tea decoction. This was followed by $20 \%$ tea concentration that showed $79 \mu \mathrm{g} / \mathrm{ml}$ of carotenoids (table 2). However, it was slightly significant than that of $5 \%$ tea concentration. Most of other samples showed significantly lower total carotenoid content, and some of them were even negligible.

Acetic acid strength was highest $(2.25 \mathrm{~g} / \mathrm{l})$ at $25^{\circ} \mathrm{C}$ with $5 \%$ tea decoction and all other samples showed significantly lower acetic acid strength (table 2). The highest ascorbic acid of $31.6 \%$ was found at $25^{\circ} \mathrm{C}$ and $5 \%$ tea concentration. This was followed by $10 \%$ $(30.2 \%)$, which was slightly lower. However, all other samples were significantly lower (table 2).

DPPH free radical scavenging activity was highest (76.95\%) with an $\mathrm{IC}_{50}$ value of $3.25 \mu \mathrm{g} / \mathrm{ml}$ at $25{ }^{\circ} \mathrm{C}$ with $5 \%$ tea decoction followed by $10 \%$ tea that showed $73.22 \%$. Other samples showed significantly lower inhibitory effect (table 2). The results indicate that there may be a direct correlation between biomass and other parameters showing higher values. Kombucha grows like a cellulose pancake or pellicle which floats on the surface of the tea broth when incubated in a static condition at room temperature for $9 \mathrm{~d}$ [13]. Acetobacter and Gluconobacter alike showed positive growth at 25,30 and $40^{\circ} \mathrm{C}$ while there was no growth at $45^{\circ} \mathrm{C}$ [14]. In the present study, kombucha grew like a pellicle on the surface of tea decoction under a static condition at $25^{\circ} \mathrm{C}$.

\section{Optimization of $\mathrm{pH}$ for biochemical parameters}

In the present investigation, SCOBY was cultivated in 5\% tea decoction which was set at different $\mathrm{pH}$ ranging from 3.5-7.5 with an interval of 0.5 . After setting the $\mathrm{pH}$ using either $0.1 \mathrm{~N} \mathrm{HCl}$ or $0.1 \mathrm{~N}$ $\mathrm{NaOH}$, tea decoction was inoculated with $1 \%$ inoculum and incubated at $25{ }^{\circ} \mathrm{C}$ either under static or rotary conditions. The results were shown (table 3 ) are only for the static condition since the data obtained for the rotary condition were insignificant. The results showed highest biomass content of $34.1 \mathrm{~g} / \mathrm{l}$ at pH 5.0 and that significantly lowered at other $\mathrm{pH}$ values. Kadare et al., (2008) [14] have shown the growth of Acetobacter and Gluconobacter at $\mathrm{pH}$ 4.5 and 7.0 while no growth was shown at $\mathrm{pH} 2.5$ and 8.5 .

All other parameters such as total carotenoids $(85 \mu \mathrm{g} / \mathrm{ml})$, acetic acid strength (4.5 g/l), ascorbic acid (33.19\%) and DPPH radical scavenging activity $(76.75 \%)$ having $\mathrm{IC}_{50}$ of $3.26 \mu \mathrm{g} / \mathrm{ml}$ were highest in fermentation at $\mathrm{pH}$ 4.5. Other samples with $\mathrm{pH}$ either acidic or alkaline showed significantly lower values for all these parameters. From the result, it is clear that even with the slight reduction in growth rate at $\mathrm{pH} 4.5$, all the biochemical parameters were higher when compared to $\mathrm{pH} 5.0$.

Table 2: Optimization of temperature on various parameters

\begin{tabular}{|c|c|c|c|c|c|c|}
\hline Temp $\left({ }^{\circ} \mathrm{C}\right)$ & Conc of tea (\%) & Biomass (g/l) & Carotenoids $(\mu \mathrm{g} / \mathrm{ml})$ & Acetic acid (g/l) & Ascorbic acid (\%) & DPPH Inhibition (\%) \\
\hline \multirow[t]{4}{*}{25} & 5 & $33.39 \pm 0.004^{\mathrm{a}}$ & $92.5 \pm 0.002^{\mathrm{a}}$ & $2.25 \pm 0.003^{\mathrm{a}}$ & $76.95 \pm 0.007^{a}$ & $31.6 \pm 0.002^{\mathrm{a}}$ \\
\hline & 10 & $32.99 \pm 0.003^{\mathrm{a}}$ & $44.5 \pm 0.004^{d}$ & $1.35 \pm 0.004^{b}$ & $30.2 \pm 0.004^{\mathrm{a}}$ & $73.22 \pm 0.008^{a}$ \\
\hline & 15 & $26.39 \pm 0.006^{b}$ & $40.0 \pm 0.005^{d}$ & $1.8 \pm 0.003^{\mathrm{a}}$ & $25.3 \pm 0.002^{\mathrm{a}}$ & $64.01 \pm 0.004^{b}$ \\
\hline & 20 & $22.50 \pm 0.005^{\mathrm{c}}$ & $79.0 \pm 0.003^{b}$ & $1.0 \pm 0.002^{\mathrm{c}}$ & $15.4 \pm 0.003^{b}$ & $49.39 \pm 0.002^{c}$ \\
\hline \multirow[t]{4}{*}{30} & 5 & $21.48 \pm 0.004^{c}$ & $59.5 \pm 0.005^{c}$ & $0.9 \pm 0.002^{c}$ & $12.6 \pm 0.002^{b}$ & $8.00 \pm 0.003^{f}$ \\
\hline & 10 & $16.27 \pm 0.003^{\mathrm{d}}$ & $15.0 \pm 0.004 \mathrm{~g}$ & $1.05 \pm 0.003^{b}$ & $14.0 \pm 0.001^{b}$ & $29.58 \pm 0.002^{e}$ \\
\hline & 15 & $18.23 \pm 0.007^{c}$ & $25.0 \pm 0.004^{\mathrm{f}}$ & $0.9 \pm 0.005^{c}$ & $13.3 \pm 0.001^{b}$ & $20.05 \pm 0.004 \mathrm{e}$ \\
\hline & 20 & $18.98 \pm 0.005^{c}$ & $15.0 \pm 0.003 \mathrm{~g}$ & $0.75 \pm 0.003^{d}$ & $11.9 \pm 0.001^{b}$ & ND \\
\hline \multirow[t]{4}{*}{35} & 5 & $17.56 \pm 0.006^{\mathrm{d}}$ & $59.5 \pm 0.002^{c}$ & $0.75 \pm 0.003^{d}$ & $14.0 \pm 0.002^{b}$ & $34.57 \pm 0.006^{d}$ \\
\hline & 10 & $17.72 \pm 0.007^{d}$ & $34.5 \pm 0.004 \mathrm{e}$ & $1.25 \pm 0.002^{\mathrm{b}}$ & $14.0 \pm 0.003^{b}$ & ND \\
\hline & 15 & $19.81 \pm 0.003^{\mathrm{c}}$ & $40.0 \pm 0.005^{\mathrm{d}}$ & $0.9 \pm 0.004^{c}$ & $13.3 \pm 0.002^{b}$ & ND \\
\hline & 20 & $22.78 \pm 0.004^{c}$ & $59.5 \pm 0.003^{c}$ & $0.9 \pm 0.005^{c}$ & $2.0 \pm 0.003^{f}$ & ND \\
\hline \multirow[t]{4}{*}{40} & 5 & $17.78 \pm 0.005^{d}$ & $0.021 \pm 0.004^{\mathrm{h}}$ & $0.6 \pm 0.006^{d}$ & $2.0 \pm 0.004^{\mathrm{f}}$ & $37.69 \pm 0.003^{d}$ \\
\hline & 10 & $20.72 \pm 0.003^{c}$ & $10.0 \pm 0.003^{g}$ & $0.75 \pm 0.004 d$ & $7.0 \pm 0.002^{\mathrm{d}}$ & $9.29 \pm 0.005^{f}$ \\
\hline & 15 & $18.32 \pm 0.006^{c}$ & $0.014 \pm 0.004^{\mathrm{i}}$ & $0.75 \pm 0.002^{d}$ & $8.4 \pm 0.003^{c}$ & $13.59 \pm 0.006$ \\
\hline & 20 & $19.72 \pm 0.004^{c}$ & $0.012 \pm 0.003^{\mathrm{i}}$ & $1.21 \pm 0.003^{b}$ & $9.1 \pm 0.003^{c}$ & ND \\
\hline \multirow[t]{4}{*}{45} & 5 & $11.71 \pm 0.008^{e}$ & $20.0 \pm 0.004^{f}$ & $0.9 \pm 0.007 \mathrm{c}$ & $5.6 \pm 0.002^{e}$ & $9.86 \pm 0.003^{f}$ \\
\hline & 10 & $15.88 \pm 0.007 \mathrm{~d}$ & $0.006 \pm 0.005^{\mathrm{i}}$ & $0.9 \pm 0.002^{c}$ & $6.3 \pm 0.001^{\mathrm{d}}$ & $38.28 \pm 0.004^{d}$ \\
\hline & 15 & $16.31 \pm 0.004^{d}$ & $0.002 \pm 0.006^{j}$ & $0.6 \pm 0.004^{d}$ & $5.6 \pm 0.002^{e}$ & $22.52 \pm 0.005^{\mathrm{e}}$ \\
\hline & 20 & $20.12 \pm 0.005^{c}$ & $0.003 \pm 0.004$ & $0.75 \pm 0.002^{d}$ & $5.6 \pm 0.002^{e}$ & ND \\
\hline
\end{tabular}

All values are mean of triplicates with SEM and are significant at $\mathrm{p}<0.05$ if the column not sharing same alphabets in the table, ND: the values were not determined

Table 3: Optimization of $\mathrm{pH}$ on various parameters in kombucha at $5 \%$ tea concentration

\begin{tabular}{|c|c|c|c|c|c|}
\hline pH & Biomass (g/l) & Carotenoids $(\mu \mathrm{g} / \mathrm{ml})$ & Acetic acid (g/l) & Ascorbic acid (\%) & DPPH Inhibition (\%) \\
\hline 3.0 & $23.07 \pm 0.005^{b}$ & $65.0 \pm 0.003^{c}$ & $2.55 \pm 0.006^{\mathrm{d}}$ & $15.40 \pm 0.002^{\mathrm{c}}$ & $34.47 \pm 0.00^{\mathrm{d}}$ \\
\hline 3.5 & $14.28 \pm 0.003^{\mathrm{d}}$ & $75.0 \pm 0.004^{b}$ & $2.55 \pm 0.004^{d}$ & $16.90 \pm 0.002^{\mathrm{c}}$ & $47.46 \pm 0.00^{c}$ \\
\hline 4.0 & $21.81 \pm 0.003^{b}$ & $30.99 \pm 0.005^{\mathrm{a}}$ & $19.33 \pm 0.00^{\mathrm{f}}$ & $77.0 \pm 0.005^{b}$ & $3.75 \pm 0.004^{\mathrm{b}}$ \\
\hline 4.5 & $31.47 \pm 0.004^{\mathrm{a}}$ & $85.0 \pm 0.006^{a}$ & $4.50 \pm 0.005^{\mathrm{a}}$ & $33.19 \pm 0.004^{\mathrm{a}}$ & $76.75 \pm 0.00^{\mathrm{a}}$ \\
\hline 5.0 & $34.10 \pm 0.005^{\mathrm{a}}$ & $84.0 \pm 0.004^{\mathrm{a}}$ & $3.75 \pm 0.003^{b}$ & $31.60 \pm 0.003^{a}$ & $55.26 \pm 0.00^{\mathrm{b}}$ \\
\hline 5.5 & $18.39 \pm 0.004^{c}$ & $62.0 \pm 0.003^{c}$ & $2.25 \pm 0.002^{\mathrm{d}}$ & $22.54 \pm 0.006^{b}$ & $30.66 \pm 0.00^{e}$ \\
\hline 6.0 & $15.50 \pm 0.006^{d}$ & $65.0 \pm 0.004^{c}$ & $3.00 \pm 0.006^{c}$ & $17.61 \pm 0.002^{\mathrm{c}}$ & $34.76 \pm 0.00^{\mathrm{d}}$ \\
\hline 6.5 & $14.87 \pm 0.003^{\mathrm{d}}$ & $53.0 \pm 0.003^{d}$ & $1.80 \pm 0.004^{\mathrm{d}}$ & $14.00 \pm 0.004^{\mathrm{d}}$ & $36.32 \pm 0.00^{\mathrm{d}}$ \\
\hline 7.0 & $8.39 \pm 0.002^{\mathrm{e}}$ & $33.0 \pm 0.004 \mathrm{e}$ & $1.20 \pm 0.005^{\mathrm{e}}$ & $13.3 \pm 0.003^{\mathrm{d}}$ & $17.77 \pm 0.00^{\mathrm{f}}$ \\
\hline 7.5 & $0.69 \pm 0.004^{f}$ & $32.0 \pm 0.005^{\mathrm{e}}$ & $0.75 \pm 0.003^{f}$ & $9.10 \pm 0.005^{\mathrm{e}}$ & $11.91 \pm 0.00 \mathrm{~g}$ \\
\hline
\end{tabular}

All values are mean of triplicates with SEM and are significant at $\mathrm{p}<0.05$ if the column not sharing same alphabets in the table 


\section{Antibacterial activity of kombucha}

Antibacterial activity of kombucha was checked against Escherichia coli, Salmonella spand Staphylococcus aureus. The result showed the largest zone of inhibition measuring $4 \mathrm{~mm}$ each with kombucha grown at $25{ }^{\circ} \mathrm{C}$ with 5 and $10 \%$ and $3 \mathrm{~mm}$ with $20 \%$ tea concentration against Escherichia coli.

There was an inhibition of $3 \mathrm{~mm}$ with kombucha grown at $25^{\circ} \mathrm{C}$ with $15 \%$ and $2 \mathrm{~mm}$ each with 5 and $10 \%$ tea concentration against Salmonella sp. However, with other samples, there was no zone of inhibition and also none of the samples showed inhibition against
Staphylococcus aureus. This indicates that kombucha grown at $25^{\circ} \mathrm{C}$ with 5 and $10 \%$ was inhibitory for Escherichia coli and $15 \%$ of tea for Salmonella sp. The antibacterial property of Kombucha may be attributed to varied strengths of acetic acid produced at different concentrations of tea. Similar antimicrobial activity against Escherichia coli and Salmonella was also reported [15, 16].

Growth inhibition of Shigella sonnei, Escherichia coli, Salmonella enteritidis and Salmonella typhimurium by the presence of antimicrobial compounds other than organic acids or proteins (enzymes) produced during fermentation or the tannins originally present in the tea broth has been shown $[17,18]$.

Table 4: Antibacterial activity of kombucha at pH 4.5

\begin{tabular}{|c|c|c|c|c|}
\hline \multirow[t]{2}{*}{ Temperature $\left({ }^{\circ} \mathrm{C}\right)$} & \multirow[t]{2}{*}{ Conc. of tea $(\mathrm{g} / 100 \mathrm{ml})$} & \multicolumn{3}{|c|}{ Percentage inhibition } \\
\hline & & Escherichia coli & Salmonella sp. & Staphylococcus aureus \\
\hline \multirow[t]{4}{*}{25} & 5 & 57.0 & 28.6 & $\mathrm{NZ}$ \\
\hline & 10 & 57.0 & 28.6 & $\mathrm{NZ}$ \\
\hline & 15 & 28.6 & 42.9 & $\mathrm{NZ}$ \\
\hline & 20 & 42.9 & 14.3 & NZ \\
\hline \multirow[t]{4}{*}{30} & 5 & $\mathrm{NZ}$ & NZ & NZ \\
\hline & 10 & NZ & NZ & NZ \\
\hline & 15 & $\mathrm{NZ}$ & NZ & NZ \\
\hline & 20 & $\mathrm{NZ}$ & $\mathrm{NZ}$ & $\mathrm{NZ}$ \\
\hline \multirow[t]{4}{*}{35} & 5 & $\mathrm{NZ}$ & $\mathrm{NZ}$ & $\mathrm{NZ}$ \\
\hline & 10 & NZ & $\mathrm{NZ}$ & NZ \\
\hline & 15 & $\mathrm{NZ}$ & $\mathrm{NZ}$ & NZ \\
\hline & 20 & $\mathrm{NZ}$ & NZ & NZ \\
\hline \multirow[t]{4}{*}{40} & 5 & NZ & NZ & NZ \\
\hline & 10 & $\mathrm{NZ}$ & $\mathrm{NZ}$ & NZ \\
\hline & 15 & $\mathrm{NZ}$ & $\mathrm{NZ}$ & $\mathrm{NZ}$ \\
\hline & 20 & $\mathrm{NZ}$ & $\mathrm{NZ}$ & $\mathrm{NZ}$ \\
\hline \multirow[t]{4}{*}{45} & 5 & $\mathrm{NZ}$ & $\mathrm{NZ}$ & $\mathrm{NZ}$ \\
\hline & 10 & $\mathrm{NZ}$ & $\mathrm{NZ}$ & $\mathrm{NZ}$ \\
\hline & 15 & $\mathrm{NZ}$ & $\mathrm{NZ}$ & NZ \\
\hline & 20 & $\mathrm{NZ}$ & $\mathrm{NZ}$ & $\mathrm{NZ}$ \\
\hline
\end{tabular}

NZ: No Inhibition zone

\section{CONCLUSION}

Kombucha is a miracle probiotic drink with tuft of health beneficial properties embedded. In the present study, it was found that different temperature and $\mathrm{pH}$ had an effect on growth and biochemical parameters such as biomass, total carotenoids, acetic acid strength, ascorbic acid, DPPH free radical scavenging activity and antimicrobial activity. The overall results indicated that kombucha grown at $25^{\circ} \mathrm{C}$ and $\mathrm{pH} 4.5-5.0$ with 5 and $10 \%$ tea concentrations were optimum for maximum activities of the abovementioned parameters.

However, there is a need to find whether it is the bacteria or yeast which is involved in the production of all the health beneficial bioactive in kombucha. It is also possible to obtain the desired quality of kombucha by controlling the fermentation conditions. Although this drink is known to people from ancient days, there is a need to create scientific awareness about its health benefits, convenient and hygienic cultural practices.

\section{ACKNOWLEDGEMENT}

The authors are thankful to the Department of Studies and Research in Microbiology, Mangalore University Post Graduate Centre, Chikka Aluvara, Kodagu-571232, Karnataka, India for providing all the necessary infrastructures to carry out this dissertation work successfully.

\section{CONFLICT OF INTERESTS}

Declared none

\section{REFERENCES}

1. Blanc PJ. Characterization of the tea fungus metabolites. Biotechnol Lett 1996;18:139-42.
2. Reiss J. Influence of different sugars on the metabolism of the tea fungus. Z Lebensm Unters Forsch 1994;198:258-61.

3. Fasching R. Tea fungus kombucha: The natural remedy and its significance in cases of cancer and other metabolic diseases. Publishing House Wilhelm Ennsthaler Austria; 1995.

4. Frank GW. Kombucha-Healthy beverage and natural remedy from the far east, $9^{\text {th }}$ Ed. Wilhelm Ennsthaler, Austria; 1995. p. 150.

5. Dufresne C, Farnworth E. Tea, kombucha and health: a review. Food Res Int 2000;33:409-21.

6. Aneja KR. Experiments in Microbiology, Plant Pathology and Biotechnology (Second Edition). New Age International Ltd. New Delhi; 2006.

7. De Ancos B, Sgroppo S, Plaza L, Cano MP. Possible nutritional and health-related value promotion in orange juice preserved by high-pressure treatment. J Sci Food Agric 2002;82:790-6.

8. Lakshminarayana R, Raju M, Krishnakantha TP, Baskaran V. Lutein and zeaxanthin in leafy greens and their bioavailability: olive oil influences the absorption of dietary lutein and its accumulation in adult rats. J Agric Food Chem 2007;55:6395-400

9. Walter S, Charles M. Determination of acetic acid content of vinegar. Natural Sciences, Baruch College New York, NY; 2010. p. 10010.

10. Deekshika B, Praveena LB, Hemanth S, Sukumaran MK Estimation of ascorbic acid content in fruits and vegetables from Hyderabad, India-A theoretical assessment of Vitamin C activity. Int J Curr Microbiol Appl Sci 2015;4:96-9.

11. Bauer AW, Kirby WM, Sherris JC, Turck M. Antibiotic susceptibility testing by a standardized single disk method. Am J Clin Pathol 1966;45:493-6.

12. Steel RGD, Torrie JH. Principles and procedures of statistics. 2 Ed. Mac Graw-Hill Singapore; 1990. 
13. Tehmeena AM, Kapil P, Sunita DD, Shashikant PV, Abhay SC. Isolation and characterization of bacteria and yeast from kombucha tea. Int J Curr Microbiol Appl Sci 2016;5:32-41.

14. Kadere TT, Miyamoto T, Oniang' O, Kutima DM, Njoroge SM. Isolation and Identification of genera Acetobacter and Gluconobacter in coconut toddy (mnazi). Afr J Biotechnol 2008;7:2963-71.

15. Cetojevi'c-Simin DD, Bogdanovic GM, Cvetkovic DD, Velicanski AS. Antiproliferative and antimicrobial activity of traditional kombucha and Satureja montana L. Kombucha. J BUON 2008;133:395-1.
16. Greenwalt CJ, Ledford RA, Steinkraus KH. Determination and characterization of the anti-microbial activity of the fermented tea kombucha. LWT Food Sci Technol 1998;31:291-6.

17. Sreeramulu G, Zhu Y, Knol W. Kombucha fermentation and its antimicrobial activity. J Agric Food Chem 2000;48:2589-94.

18. Sreeramulu G, Zhu Y, Knol W. Characterization of antimicrobial activity in kombucha fermentation. Acta Biotechnol 2001;21:49-6.

\section{How to cite this article}

- Sumaiya Ahmed Ali, Gunashree B Shivanna. Physico-chemical characteristics of russian tea fungus: kombucha. Int J Pharm Pharm Sci 2017;9(4):161-165. 